\title{
KETAHANAN CAMPURAN AC-WC MENGGUNAKAN LATEKS TERHADAP AIR
}

\author{
Sri Sunarjono \\ Prodi Magister Teknik Sipil \\ Fakultas Teknik \\ Universitas Muhammadiyah \\ Surakarta \\ Sri.Sunarjono@ums.ac.id
}

\author{
Nurul Hidayati \\ Prodi Magister Teknik Sipil \\ Fakultas Teknik \\ Universitas Muhammadiyah \\ Surakarta \\ Nurul.Hidayati@ums.ac.id
}

\author{
Adi Indra Pratama \\ Prodi Teknik Sipil \\ Fakultas Teknik \\ Universitas Muhammadiyah \\ Surakarta \\ adiindra64@gmail.com
}

\begin{abstract}
This paper presents the results of research on the durability of Asphalt Concrete-Wear Asphalt (AC-WC) mixture using latex material to water immersion. Resistance to warm water immersion is intended to measure the durability of asphalt mixture in serving traffic loads against the influence of water and temperature factors. The use of latex material is intended to improve the performance of the mixture. This research uses a laboratory-scale test. The specimen of AC-WC added with latex was tested for its tensile strength using the Indirect Tensile Strength (ITS) test. Other specimens are immersed in water at $60^{\circ} \mathrm{C}$ with a continuous and periodic soaking system. The continuous immersion was carried out for $0,24,48$, and 72 hours, while the periodic immersion was carried out for 12 hours soaked and 12 hours exposed alternately. The durability was analyzed using the Residual Strength Index indicator. The analysis shows that the addition of latex increased the tensile strength of the AC-WC mixture based on the ITS test results. The AC-WC mixture added with latex can increase its resistance to continuous and periodic immersion, by increasing the residual strength index and decreasing IKS with increasing immersion time. Continuous immersion has a greater impact on reducing IKS than periodic. In specimens without latex, the decrease in IKS values between continuous and periodic soaking has the same pattern, but in specimens with latex, the pattern is different.
\end{abstract}

Keywords: asphalt concrete; latex; water immersion; Indirect Tensile Strength; Residual Strength Index.

\begin{abstract}
Abstrak
Makalah ini menyajikan hasil penelitian mengenai ketahanan campuran beraspal Asphalt Concrete-Wearing Course (AC-WC) yang menggunakan bahan lateks terhadap rendaman air. Ketahanan terhadap perendaman air hangat dimaksudkan untuk mengukur daya tahan campuran aspal dalam melayani beban lalu lintas terhadap pengaruh faktor air dan temperatur. Penggunaan bahan lateks dimaksudkan untuk memperbaiki kinerja campuran. Penelitian ini menggunakan uji skala laboratorium. Kekuatan tarik benda uji AC-WC dengan lateks diuji menggunakan uji Indirect Tensile Strength (ITS). Benda uji yang lain direndam dalam air bertemperatur $60^{\circ} \mathrm{C}$ dengan sistem rendaman menerus dan rendaman berkala. Metode perendaman secara menerus dilakukan selama 0, 24 jam, 48 jam, dan 72 jam, sedangkan rendaman secara berkala dilakukan 12 jam direndam dan 12 jam diekspose secara bergantian. Tingkat keawetan dianalisis menggunakan indikator Indeks Kekuatan Sisa (IKS). Hasil analisis menunjukkan bahwa penambahan lateks meningkatkan kekuatan tarik campuran AC-WC berdasarkan hasil uji ITS. Ketahanan terhadap perendaman menerus dan berkala, campuran AC-WC menggunakan lateks meningkat, dengan meningkatnya indeks kekuatan sisa dan menurunnya IKS dengan bertambahnya lama rendaman. Perendaman secara menerus memberi dampak yang lebih besar dalam menurunkan IKS dibanding perendaman berkala. Pada benda uji tanpa lateks, penurunan nilai IKS antara rendaman menerus dan rendaman berkala memiliki pola yang sama, namun pada benda uji dengan lateks pola penurunan nilai IKS berbeda.
\end{abstract}

Kata-kata kunci: campuran beraspal; lateks; rendaman air; Indirect Tensile Strength; Indeks Kekuatan Sisa.

\section{PENDAHULUAN}

Asphalt Concrete-Wearing Course (AC-WC) adalah salah satu jenis bahan perkerasan jalan tipe lentur (flexible pavement) yang paling atas dalam struktur perkerasan. 
Lapisan ini berfungsi sebagai lapis aus dan untuk memproteksi perkerasan dari pengaruh air hujan dan perubahan temperatur. Lapisan ini juga harus memiliki kekuatan yang memadai untuk mengimbangi terjadinya tegangan beban roda yang tinggi. Meskipun sebagai lapis nonstruktural, tetapi lapisan AC-WC ini dapat menambah daya tahan (keawetan) dan masa pelayanan konstruksi perkerasan secara keseluruhan (Ditjen Bina Marga, 2010).

Perkerasan jalan di wilayah beriklim tropis mengalami 2 kondisi, yaitu jalan terendam air dan jalan kering. Oleh karenanya, material jalan perlu dipersiapkan memiliki ketahanan terhadap rendaman air, agar mampu mewujudkan layanan beban lalu lintas hingga akhir umur rencananya. Menurut Lee (1969) dan Harnaeni et al. (2018), faktor air dapat menurunkan ketahanan perkerasan jalan dalam melayani lalu lintas. Sulistiyatno et al. (2012) menyatakan bahwa banjir mengakibatkan jalan menjadi rusak, sehingga menyebabkan umur rencana jalan berkurang.

Keawetan (durabilitas) adalah ketahanan suatu struktur perkerasan jalan dalam menerima beban lalu lintas kendaraan dan menahan kerusakan akibat cuaca dan iklim, seperti udara, air, atau perubahan temperatur (Sukirman, 2003). Agregat merupakan material yang rentan terkena kerusakan oleh air, karena sifatnya yang hydrophobic (Tajudin dan Suparma, 2017). Infiltrasi air ke dalam rongga udara dalam campuran menyebabkan terjadinya pelunakan pada aspal (Putra, 2016). Air juga dapat mengurangi kohesi antara aspal dan air, yang dapat merusak ikatan antara aspal dan agregat dalam campuran (Putri dan Suparma, 2009). Semakin lama campuran beraspal terendam air, nilai stabilitasnya cenderung menurun (Nahyo et al., 2015).

Penyebab kerusakan perkerasan jalan di Indonesia bersifat multifaktor, yang merupakan kombinasi faktor beban, pengaruh iklim, kualitas material, serta manajemen pengerjaan konstruksi jalan. Jenis kerusakan yang terjadi juga merupakan kombinasi kerusakan retak kelelahan dan rutting. Salah satu upaya untuk meningkatkan ketahanan bahan perkerasan terhadap faktor perusak adalah dengan memberikan bahan tambah (additive) pada campuran beraspal. Bahan tambah ini mampu meningkatkan propertis aspal sesuai dengan kebutuhan.

Modifikasi aspal bertujuan untuk meningkatkan kualitas aspal yang akan digunakan dalam pembuatan atau perbaikan jalan (Rianung, 2007). Modifikasi aspal dengan lateks diperoleh dengan mencampurkan material lateks dengan konsentrasi tertentu ke dalam aspal (Prastanto et al., 2018). Trisilvana et al. (2016) mengatakan bahwa pemakaian lateks mengakibatkan terjadinya penurunan nilai penetrasi, peningkatan titik lembek, peningkatan titik nyala, dan peningkatan Marshall Quotient. Penambahan lateks juga meningkatkan ketahanan terhadap kerusakan yang disebabkan oleh air karena interlocking antaragregat semakin baik (Amiruddin et al., 2012). Salah satu bahan tambah yang dapat digunakan adalah lateks, yang merupakan getah yang berasal dari pohon karet (Amal, 2011). Lateks digunakan karena memiliki durabilitas dan elastisitas yang baik (Wijaya et al., 2016). Sutanto et al. (2018a,b) menyatakan bahwa aspal yang dicampur lateks mampu mereduksi penuaan aspal akibat pengaruh iklim dan cuaca, menurunkan nilai penetrasi, meningkatkan titik lembek, dan menunjukkan meningkatkan ketahanan terhadap rutting. Menurut Siswanto (2017), lateks mampu menurunkan laju deformasi, sedangkan Wen et al. (2015) menyatakan lateks 
mampu mengurangi sensitivitas temperatur dan efektif meningkatkan ketahanan terhadap rutting, namun pada temperatur tinggi lateks justru menurunkan ketahanan terhadap rutting campuran beraspal (Al-Mansob et al., 2014). Siswanto (2019) menambahkan bahwa penambahan lateks dapat mengurangi kebutuhan akan aspal.

Penelitian ini dimaksudkan untuk melakukan pendalaman ketahanan campuran ACWC menggunakan lateks terhadap rendaman air bertemperatur $60^{\circ} \mathrm{C}$ dengan sistem menerus dan bertahap. Pengujian yang digunakan adalah Indirect Tensile Strength (ITS), dengan parameter evaluasi sisa kekuatan setelah benda uji direndam atau disebut dengan Indeks Kekuatan Sisa (IKS).

ITS adalah suatu metode untuk mengetahui nilai gaya tarik campuran beraspal. Parameter gaya tarik tersebut dapat digunakan untuk mengevaluasi potensi retakan (fatigue) pada campuran beraspal. Sifat uji ini adalah kegagalan gaya tarik yang berguna untuk memperkirakan potensial retakan. Gaya tarik tidak langsung dapat dihitung menggunakan Rumus 1 (BSN, 2015).

$$
I T S=\frac{2000 \times \mathrm{P}}{\pi \times \mathrm{d} \times \mathrm{h}}
$$

dengan:

$\mathrm{P} \quad=$ Beban maksimum $(\mathrm{N})$;

$\mathrm{h} \quad=$ Tinggi benda uji $(\mathrm{mm})$;

$\mathrm{d} \quad=$ Diameter benda uji $(\mathrm{mm})$;

ITS = Nilai kuat tarik secara tidak langsung $(\mathrm{kPa})$.

IKS diperoleh melalui pengujian terhadap sifat mekanik benda uji (ITS), yang dibagi dalam dua kelompok. Pengujian kelompok pertama tanpa direndam $\left(S_{1}\right)$, dan pengujian kelompok kedua setelah direndam $\left(S_{2}\right)$. Nilai ITS yang diperoleh pada kedua perendaman tersebut digunakan untuk menentukan IKS, dengan menggunakan Rumus 2 (BSN, 2015).

$$
I K S=\frac{S_{2}}{S_{1}} \times 100 \%
$$

dengan:

$\mathrm{S}_{1}=$ Nilai rata-rata pengujian ITS tanpa rendaman $(\mathrm{kPa})$;

$\mathrm{S}_{2}=$ Nilai rata-rata pengujian ITS dengan rendaman $(\mathrm{kPa}) ;$

IKS = Indeks Kekuatan Sisa (\%).

\section{METODE PENELITIAN}

Penelitian ini dilakukan melalui pendekatan dengan uji skala laboratorium. Benda uji campuran AC-WC dibuat pada kadar aspal optimum (KAO) sebesar 5,5\%, sedangkan kadar lateks menggunakan hasil penelitian Thanaya et al. (2016), yaitu sebesar 4\%. Penelitian ini menggunakan 2 metode rendaman, yaitu rendaman menerus dan rendaman berkala, dengan 
air tawar bertemperatur $60^{\circ} \mathrm{C}$. Rendaman menerus dilakukan dengan variasi, yaitu 0,24 jam, 48 jam, dan 72 jam. Rendaman berkala mempunyai 2 siklus, yaitu rendam (r) dan ekspose (e) dengan durasi masing-masing 12 jam secara bergantian, yang variasinya seperti terlihat pada Tabel 1 .

Tabel 1 Variasi dan Jumlah Benda Uji

\begin{tabular}{ccccc}
\hline \multirow{2}{*}{ No. } & Rendaman & \multicolumn{2}{c}{ Jumlah Benda Uji } & \multirow{2}{*}{ Total } \\
\cline { 3 - 4 } & (jam) & Tanpa Lateks & Dengan Lateks & \\
\hline & Menerus & 3 & 3 & 6 \\
1 & 0 & 3 & 3 & 6 \\
2 & 24 & 3 & 3 & 6 \\
3 & 48 & 3 & 3 & 6 \\
4 & 72 & 3 & 3 & 6 \\
\hline & Berkala & 3 & 3 & 6 \\
1 & 0 & 3 & 3 & 6 \\
2 & $12 \mathrm{r}-12 \mathrm{e}$ & 3 & 3 & 6 \\
\hline
\end{tabular}

\section{HASIL DAN PEMBAHASAN}

\section{Kekuatan Tarik Campuran AC-WC Menggunakan Lateks}

Sebelum membahas ketahanan campuran AC-WC menggunakan lateks terhadap rendaman air, perlu diketahui kekuatan tarik campuran AC-WC. Kekuatan tarik campuran dievaluasi menggunakan uji ITS. Benda uji dibuat dengan 2 variasi, yaitu tanpa lateks (TL) dan dengan lateks (DL). Hasil pengujian kemudian dianalisis dan ditampilkan pada Tabel 2 dan Gambar 1.

Tabel 2 Hasil Pengujian ITS

\begin{tabular}{ccccc}
\hline No. & $\begin{array}{c}\text { Lateks } \\
(\%)\end{array}$ & $\begin{array}{c}\text { Pembacaan Dial } \\
(\mathrm{lb})\end{array}$ & $\begin{array}{c}\text { ITS } \\
(\mathrm{kPa})\end{array}$ & $\begin{array}{c}\text { Rata-Rata ITS } \\
(\mathrm{kPa})\end{array}$ \\
\hline 1 & & 52 & 765 & \\
2 & $0 \%$ & 52 & 765 & 789 \\
3 & & 57 & 838 & \\
\hline 1 & & 63 & 926 & \\
2 & $4 \%$ & 57 & 838 & 915 \\
3 & & 67 & 981 & \\
\hline
\end{tabular}

Berdasarkan Tabel 2 dan Gambar 1 dapat diketahui nilai rata-rata ITS benda uji tanpa lateks sebesar $789 \mathrm{kPa}$, dan dengan lateks sebesar $915 \mathrm{kPa}$. Penambahan lateks meningkatkan kekuatan tarik campuran, sehingga nilai ITS naik. Peningkatan kekuatan campuran ini diperkirakan karena penambahan lateks memperbaiki karakteristik aspal. Hal ini didukung oleh Usman et al. (2019), Sani et al. (2019), Kamal et al. (2020), dan Abdulrahman et al. (2020), yang menyatakan bahwa bahan lateks mampu memperbaiki sifat aspal, yaitu nilai penetrasi, titik lembek, stiffness, viskositas, dan ketahanan terhadap rutting. 


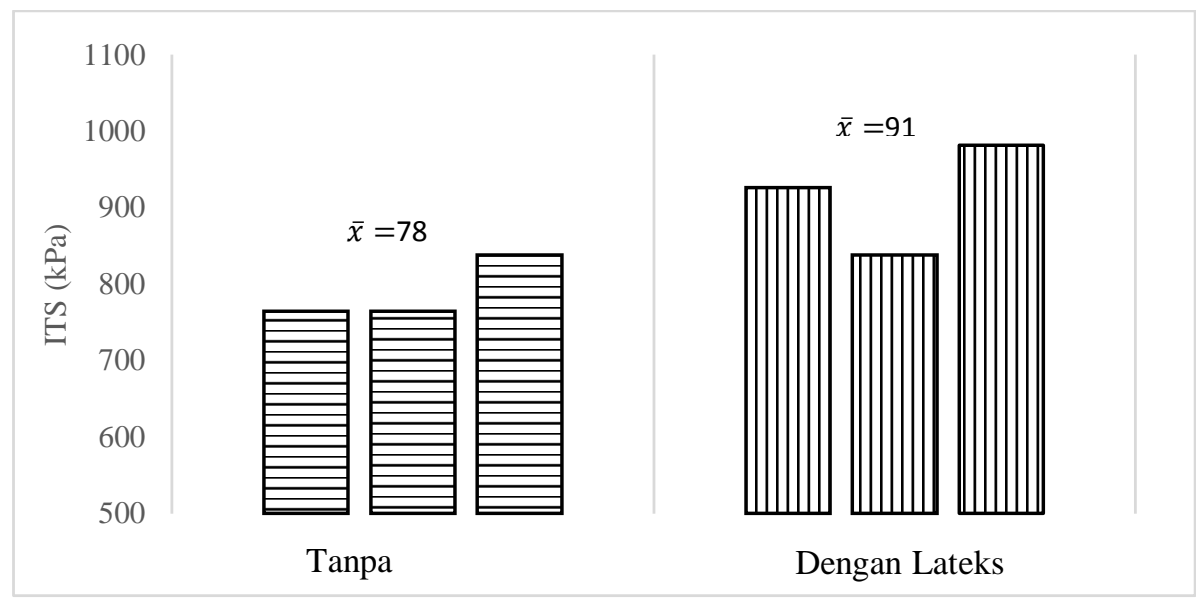

Gambar 1 Perbandingan antara Benda Uji Tanpa Lateks dan Dengan Lateks

\section{Ketahanan Campuran AC-WC terhadap Rendaman Menerus}

Rendaman menerus dimaksudkan bahwa benda uji direndam dalam air bertemperatur $60^{\circ} \mathrm{C}$ selama durasi tertentu (24 jam, 48 jam, dan 72 jam). Setelah selesai direndam, benda uji diuji ITS dan dianalisis nilai IKS-nya. Tabel 3 dan Gambar 2 menampilkan hasil uji ITS benda uji direndam menerus disertai analisis IKS-nya.

Tabel 3 Hasil Uji ITS dan Analisis IKS Benda Uji Direndam Menerus

\begin{tabular}{|c|c|c|c|c|c|c|c|c|c|}
\hline \multirow{2}{*}{$\begin{array}{c}\text { Durasi } \\
\text { (jam) }\end{array}$} & \multirow{2}{*}{ No. } & \multicolumn{2}{|c|}{ Pembacaan Dial (lb) } & \multicolumn{2}{|c|}{ ITS $(\mathrm{kPa})$} & \multicolumn{2}{|c|}{ Rata-Rata ITS $(\mathrm{kPa})$} & \multicolumn{2}{|c|}{ IKS (\%) } \\
\hline & & TL & DL & TL & DL & TL & DL & $\mathrm{TL}$ & $\mathrm{DL}$ \\
\hline \multirow{3}{*}{0} & 1 & 52 & 63 & 765 & 926 & \multirow{3}{*}{789} & \multirow{3}{*}{915} & \multirow{3}{*}{ - } & \multirow{3}{*}{-} \\
\hline & 2 & 52 & 57 & 765 & 838 & & & & \\
\hline & 3 & 57 & 67 & 838 & 981 & & & & \\
\hline \multirow{3}{*}{24} & 1 & 52 & 59 & 765 & 871 & \multirow{3}{*}{745} & \multirow{3}{*}{911} & \multirow{3}{*}{94} & \multirow{3}{*}{99} \\
\hline & 2 & 54 & 63 & 794 & 926 & & & & \\
\hline & 3 & 46 & 63 & 676 & 934 & & & & \\
\hline \multirow{3}{*}{48} & 1 & 57 & 59 & 842 & 882 & \multirow{3}{*}{733} & \multirow{3}{*}{904} & \multirow{3}{*}{93} & \multirow{3}{*}{99} \\
\hline & 2 & 46 & 63 & 682 & 945 & & & & \\
\hline & 3 & 46 & 59 & 676 & 885 & & & & \\
\hline \multirow{3}{*}{72} & 1 & 46 & 63 & 679 & 942 & \multirow{3}{*}{708} & \multirow{3}{*}{891} & \multirow{3}{*}{90} & \multirow{3}{*}{97} \\
\hline & 2 & 46 & 57 & 676 & 848 & & & & \\
\hline & 3 & 52 & 59 & 768 & 882 & & & & \\
\hline
\end{tabular}

Keterangan: $\mathrm{TL}=$ Tanpa Lateks

$\mathrm{DL}=$ Dengan Lateks

Tabel 3 dan Gambar 2 menunjukkan bahwa benda uji tanpa lateks memiliki nilai ITS rata-rata tertinggi sebesar $789 \mathrm{kPa}$ dan nilai ITS terendah sebesar $708 \mathrm{kPa}$. Benda uji dengan lateks memiliki nilai ITS rata-rata tertinggi, yaitu $915 \mathrm{kPa}$ dan nilai ITS rata-rata terendah $891 \mathrm{kPa}$. Berdasarkan Gambar 2 juga dapat diketahui bahwa kedua jenis benda uji, baik dengan ataupun tanpa lateks mengalami penurunan nilai ITS ketika direndam lebih lama. Namun demikian, benda uji dengan lateks menunjukkan penurunan yang jauh lebih landai dibanding benda uji tanpa lateks. Oleh karena itu, dapat dikatakan bahwa benda uji dengan lateks lebih memiliki ketahanan terhadap rendaman menerus dibandingkan dengan benda uji tanpa lateks. 


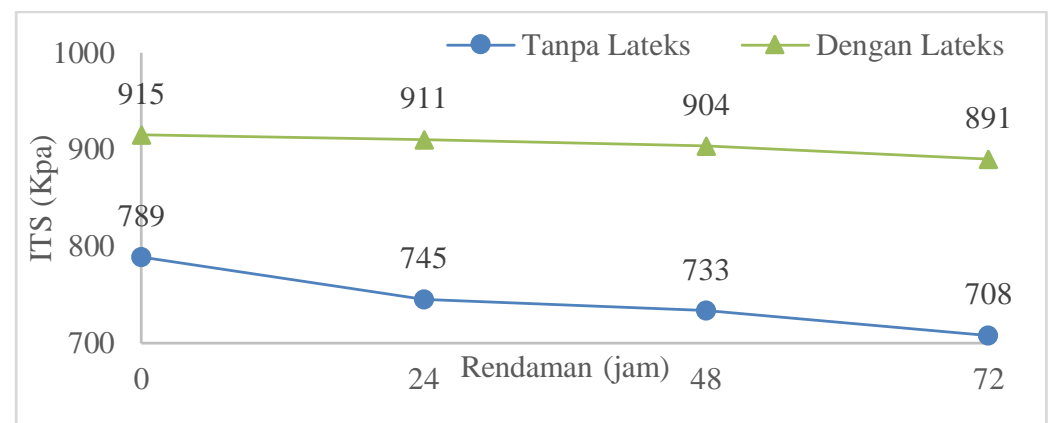

Gambar 2 Nilai ITS Benda Uji Setelah Direndam Menerus

Penurunan tertinggi pada benda uji tanpa lateks terjadi pada rendaman 24 jam, sedangkan pada benda uji dengan lateks terjadi pada rendaman 72 jam. Nilai penurunan kekuatan benda uji terhadap pengaruh rendaman dapat dianalisis dengan nilai IKS. Berdasarkan Persamaan (2) dapat dihitung nilai IKS yang ditampilkan pada Gambar 3.

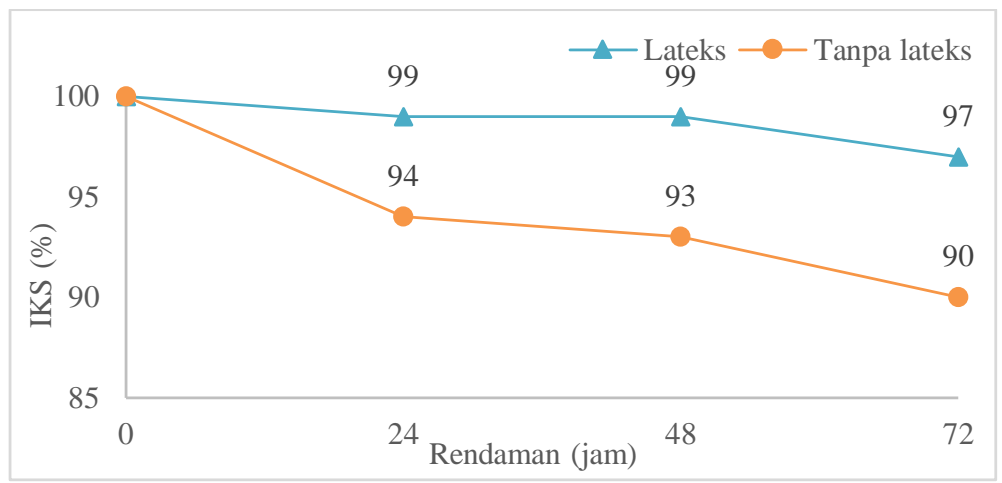

Gambar 3 Nilai IKS Benda Uji Setelah Direndam Secara Menerus

Gambar 3 menunjukkan bahwa hasil perhitungan nilai IKS benda uji dengan dan tanpa lateks setelah direndam menerus selama 24 jam, 48 jam, dan 72 jam. Satu variasi benda uji tidak direndam sebagai nilai pembanding perhitungan IKS. Berdasarkan Gambar 3 tampak bahwa penurunan nilai IKS benda uji tanpa lateks jauh lebih tajam dibanding penurunan nilai IKS benda uji dengan lateks. Hal ini berarti bahwa campuran menggunakan lateks mempunyai keawetan yang jauh lebih baik. Nilai keawetan campuran menggunakan lateks diperkirakan karena pengaruh peningkatan sifat aspal setelah dicampur dengan lateks. Hal ini didukung oleh Abdulrahman et al. (2020), yang menyatakan bahwa bahan aspal yang dimodifikasi dengan lateks memiliki nilai kohesi, adhesi, dan ketahanan terhadap air dan temperatur yang lebih baik.

\section{Ketahanan Campuran AC-WC terhadap Rendaman Berkala}

Rendaman berkala dimaksudkan bahwa benda uji direndam dalam air bertemperatur $60^{\circ} \mathrm{C}$ secara berkala, yaitu separuh waktu direndam (r) dan separuh waktu diekspose (e). Komposisi durasi rendaman 24 jam adalah 12 jam direndam (12r) dan 12 jam diekspose (12e). Hasil pengujian ITS dan analisis IKS dipresentasikan pada Tabel 4 dan Gambar 4. 
Tabel 4 Hasil Uji ITS dan Analisis IKS Benda Uji Direndam Menerus

\begin{tabular}{|c|c|c|c|c|c|c|c|c|c|}
\hline \multirow{2}{*}{$\begin{array}{c}\text { Durasi } \\
\text { (jam) }\end{array}$} & \multirow{2}{*}{ No. } & \multicolumn{2}{|c|}{ Pembacaan Dial (lb) } & \multicolumn{2}{|c|}{ ITS $(\mathrm{kPa})$} & \multicolumn{2}{|c|}{ Rata-Rata ITS (kPa) } & \multicolumn{2}{|c|}{ IKS (\%) } \\
\hline & & $\mathrm{TL}$ & DL & $\mathrm{TL}$ & $\mathrm{DL}$ & TL & DL & $\mathrm{TL}$ & DL \\
\hline \multirow{3}{*}{0} & 1 & 52 & 63 & 765 & 926 & \multirow{3}{*}{789} & \multirow{3}{*}{915} & \multirow{3}{*}{ - } & \multirow{3}{*}{-} \\
\hline & 2 & 52 & 57 & 765 & 838 & & & & \\
\hline & 3 & 57 & 67 & 838 & 981 & & & & \\
\hline \multirow{3}{*}{24} & 1 & 47 & 63 & 700 & 934 & \multirow{3}{*}{760} & \multirow{3}{*}{914} & \multirow{3}{*}{96} & \multirow{3}{*}{100} \\
\hline & 2 & 54 & 59 & 804 & 875 & & & & \\
\hline & 3 & 52 & 63 & 777 & 934 & & & & \\
\hline \multirow{3}{*}{48} & 1 & 47 & 63 & 700 & 949 & \multirow{3}{*}{749} & \multirow{3}{*}{908} & \multirow{3}{*}{95} & \multirow{3}{*}{99} \\
\hline & 2 & 52 & 59 & 774 & 885 & & & & \\
\hline & 3 & 52 & 59 & 774 & 889 & & & & \\
\hline \multirow{3}{*}{72} & 1 & 47 & 63 & 700 & 942 & \multirow{3}{*}{723} & \multirow{3}{*}{904} & \multirow{3}{*}{92} & \multirow{3}{*}{99} \\
\hline & 2 & 47 & 59 & 700 & 889 & & & & \\
\hline & 3 & 52 & 59 & 771 & 882 & & & & \\
\hline
\end{tabular}

Keterangan: $\mathrm{TL}=$ Tanpa Lateks $\mathrm{r}=$ rendam

DL $=$ Dengan Lateks $\quad \mathrm{e}=$ ekspose

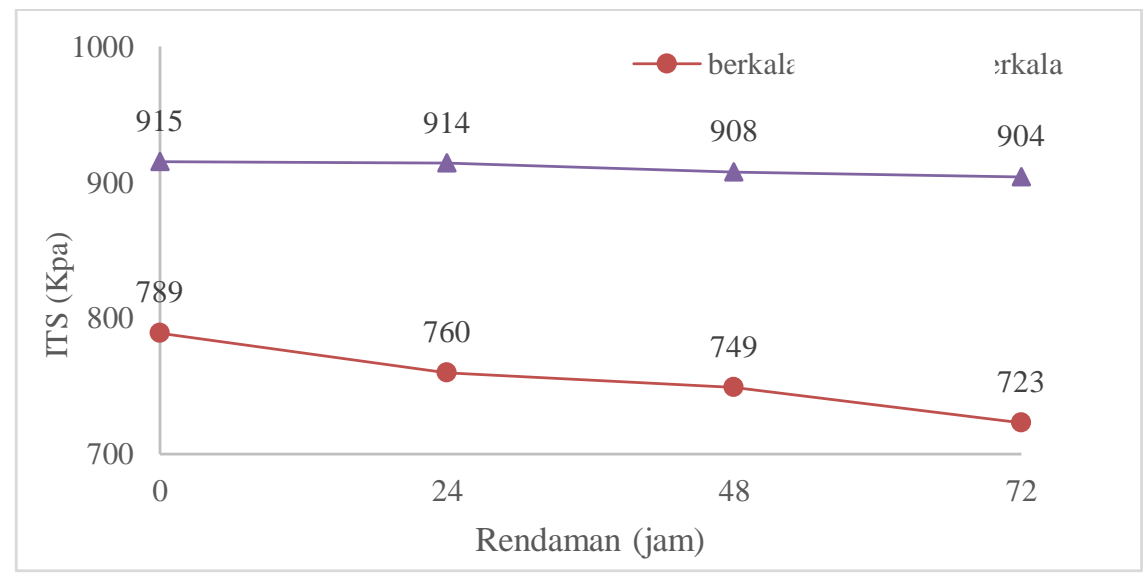

Gambar 4 Nilai ITS Benda Uji Setelah Direndam Berkala

Tabel 4 dan Gambar 4 menunjukkan bahwa nilai tertinggi rata-rata ITS benda uji tanpa lateks adalah $789 \mathrm{kPa}$ dan nilai terendah rata-rata ITS adalah $723 \mathrm{kPa}$. Nilai tertinggi rata-rata ITS benda uji dengan lateks adalah $915 \mathrm{kPa}$ dan nilai terendah rata-rata ITS adalah $904 \mathrm{kPa}$. Penurunan tertinggi pada benda uji tanpa lateks terjadi pada rendaman 24 jam, sedangkan pada benda uji dengan lateks terjadi pada rendaman 48 jam. Nilai ITS paling rendah terjadi pada rendaman 72 jam. Penambahan lateks mengakibatkan penurunan nilai ITS yang lebih kecil. Semakin lama rendaman nilai ITS yang dihasilkan semakin kecil.

Gambar 5 menunjukkan nilai indeks kekuatan sisa (IKS) dari 2 variasi benda uji. Penurunan tertinggi nilai IKS terjadi pada benda uji tanpa lateks rendaman 24 jam. Benda uji dengan lateks mengalami penurunan pada rendaman 48 jam dan dapat dipertahankan sampai 72 jam. Nilai IKS 2 variasi paling kecil berada di rendaman 72 jam. Penambahan lateks mengakibatkan penurunan yang lebih kecil dibanding tanpa lateks. Semakin lama rendaman, Nilai IKS semakin turun. 


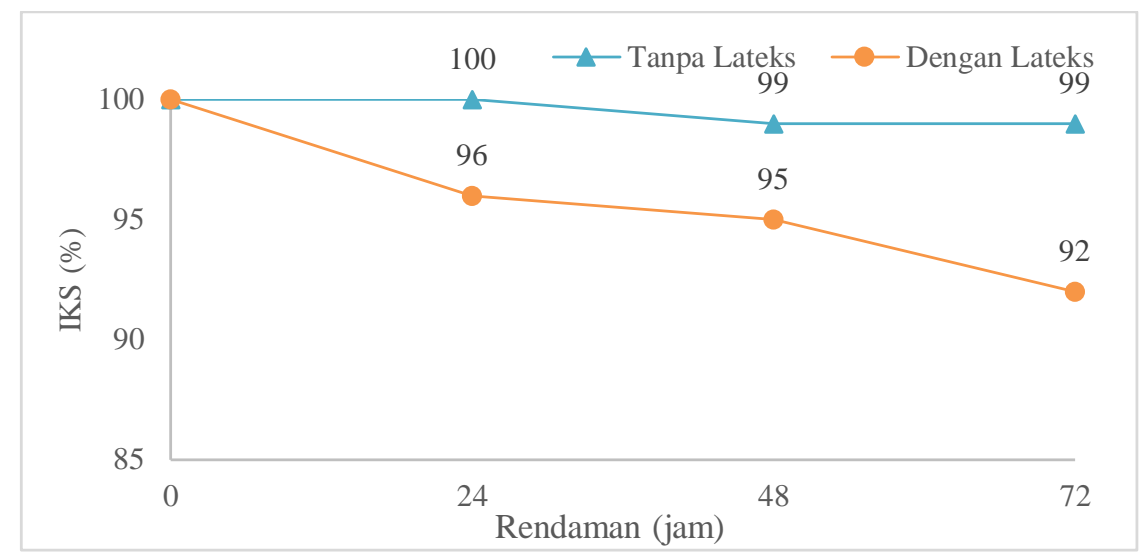

Gambar 5 Nilai IKS Benda Uji Setelah Direndam Secara Berkala

Metode rendaman berkala, yaitu direndam dan diekspose, memberikan pengaruh penurunan nilai ITS dan IKS kedua variasi benda uji. Ketika kondisi direndam, benda uji akan kenyang air dan saat diekspose akan menguapkan air yang berada di seluruh bagian, sehingga benda uji berubah menjadi kering air. Perubahan kondisi ini mengakibatkan kekuatan campuran mengalami penurunan.

Aspal yang dicampur lateks akan meningkatkan nilai ketahanan terhadap temperatur. Pada rendaman berkala terjadi siklus naik turunnya temperatur, ketika direndam benda uji berada di temperatur $60^{\circ} \mathrm{C}$ dan ketika diekspose di temperatur sekitar $25^{\circ} \mathrm{C}$. Lateks mampu mempertahankan kekuatan aspal dalam mengikat butiran agregat. Hal ini menyebabkan kekuatan aspal menjadi lebih baik dan mampu mempertahankan kekuatan tariknya dalam temperatur rendaman yang tinggi dan temperatur ekspose yang rendah. Lateks akan mengeras ketika berada di temperatur yang rendah dan bersifat kedap air. Sifat ini dibawa ke dalam aspal sehingga air akan sulit mengganggu kinerja aspal.

\section{Perbandingan Pengaruh Rendaman Menerus dan Berkala}

Berdasarkan hasil yang telah ditampilkan, dapat dibuat perbandingan pengaruh 2 metode rendaman air bertemperatur $60^{\circ} \mathrm{C}$ secara menerus dan secara berkala. Perbandingan dilakukan dengan menggunakan perubahan nilai IKS 2 variasi benda uji, yaitu tanpa dan dengan lateks. Perbandingan pertama menggunakan benda uji tanpa lateks dengan membandingkan rendaman menerus dan rendaman berkala, seperti yang ditampilkan pada Gambar 6 .

Berdasarkan Gambar 6 dapat diketahui penurunan tertinggi rendaman menerus pada 24 jam. Penurunan nilai IKS tertinggi rendaman berkala juga terjadi pada rendaman 24 jam. Rendaman menerus mengakibatkan penurunan yang lebih tinggi dibandingkan dengan rendaman berkala. Pada penelitian ini, lama waktu efektif rendaman lebih berpengaruh daripada efek perubahan rendaman atau ekspose dan perubahan temperatur $60^{\circ} \mathrm{C}$ dan $25^{\circ} \mathrm{C}$. Pola penurunan nilai IKS kedua cara rendaman adalah sama. Hal ini menunjukkan bahwa pengaruh lama rendaman dan perubahan cara rendaman bersifat linier. Namun belum diketahui pengaruh frekuensi perubahan cara rendaman. 


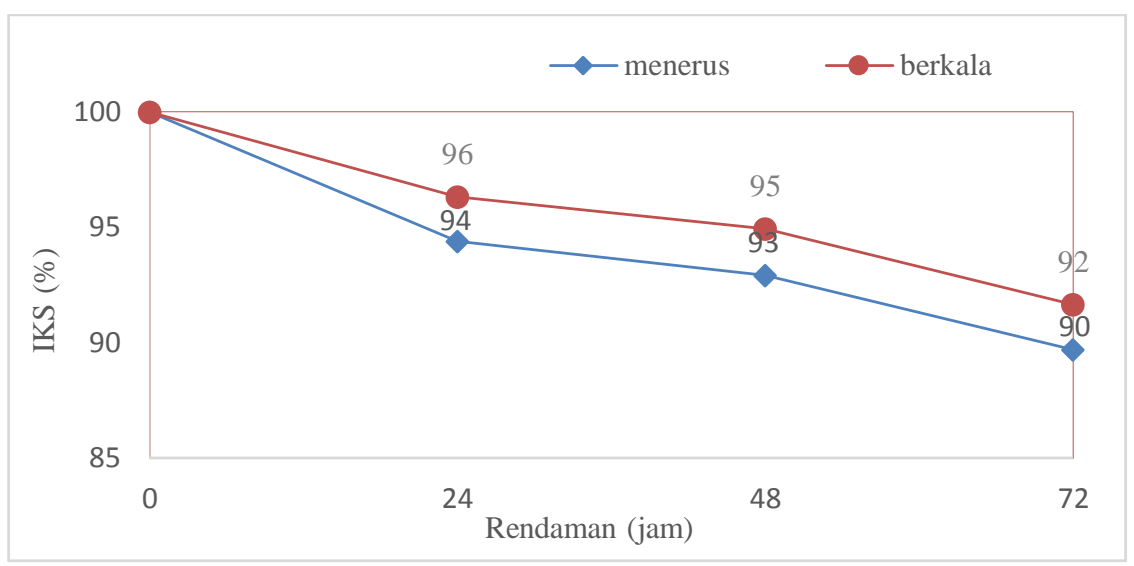

Gambar 6 Perbandingan antara Rendaman Menerus dan Berkala terhadap Nilai IKS Benda Uji Tanpa Lateks

Perbandingan kedua menggunakan benda uji dengan lateks yang hasilnya berupa pola penurunan nilai IKS akibat rendaman menerus dan berkala ditunjukkan pada Gambar 7. Sebagaimana kasus pada benda uji tanpa lateks, benda uji dengan lateks yang direndam menerus juga mengalami penurunan yang lebih tinggi dibandingkan dengan direndam berkala. Meskipun demikian, besar penurunan kedua jenis rendaman berbeda, dengan bertambahnya lama perendaman, dan pengaruh rendaman menerus lebih besar dalam menurunkan nilai IKS. Hal ini menunjukkan bahwa benda uji dengan lateks lebih kurang tahan terhadap cara rendaman menerus.

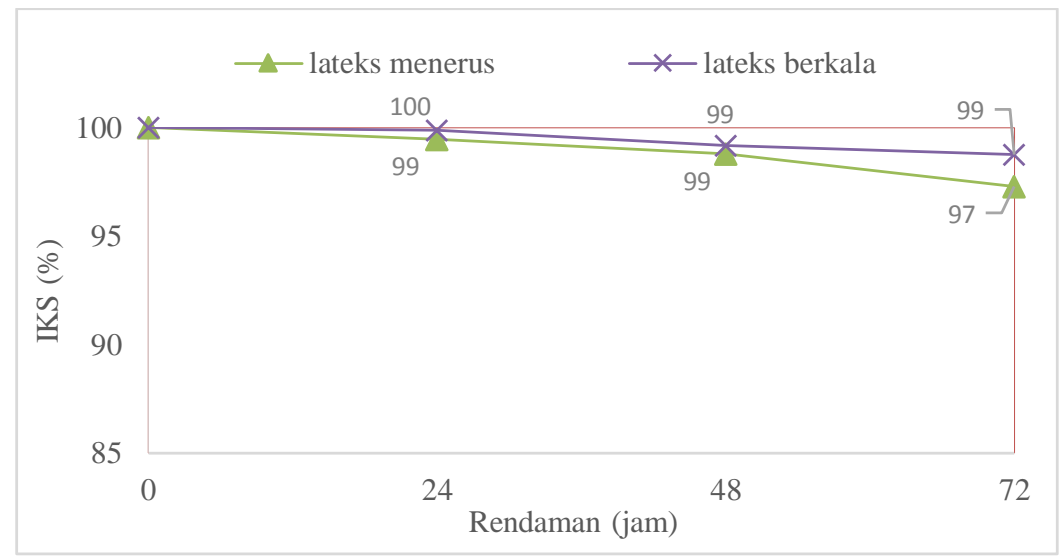

Gambar 7 Hubungan antara Metode Rendaman dan IKS Benda Uji dengan Lateks

Gambar 8 menunjukkan perbandingan pengaruh rendaman menerus dan rendaman berkala pada kedua jenis variasi benda uji tanpa dan dengan lateks. Berdasarkan Gambar 8, benda uji dengan lateks terlihat lebih superior dibandingkan benda uji tanpa lateks dalam hal ketahanan terhadap rendaman air. Lateks juga memberi pengaruh mereduksi penurunan nilai IKS pada penambahan lama rendaman. Hingga rendaman hari ketiga, kekuatan sisa benda uji dengan lateks hanya turun 3\% untuk menerus, sementara benda uji tanpa lateks turun hingga $10 \%$, yang mencapai batas maksimal penurunan menurut spesifikasi Ditjen Bina Marga (2010). 
Hal yang menarik adalah pengaruh cara rendaman terhadap kedua jenis variasi benda uji memiliki perbedaan. Pengaruh jenis rendaman terhadap benda uji tanpa lateks tidak terlihat kecuali jenis menerus lebih menyebabkan penurunan IKS lebih besar, namun pola penurunan sama dan linear. Benda uji tanpa lateks terlihat mengalami penurunan IKS semakin tajam pada hari ketiga (72 jam). Pengaruh jenis rendaman terhadap benda uji dengan lateks terlihat memiliki perbedaan. Semakin lama rendaman, semakin besar penurunan IKS pada rendaman menerus.

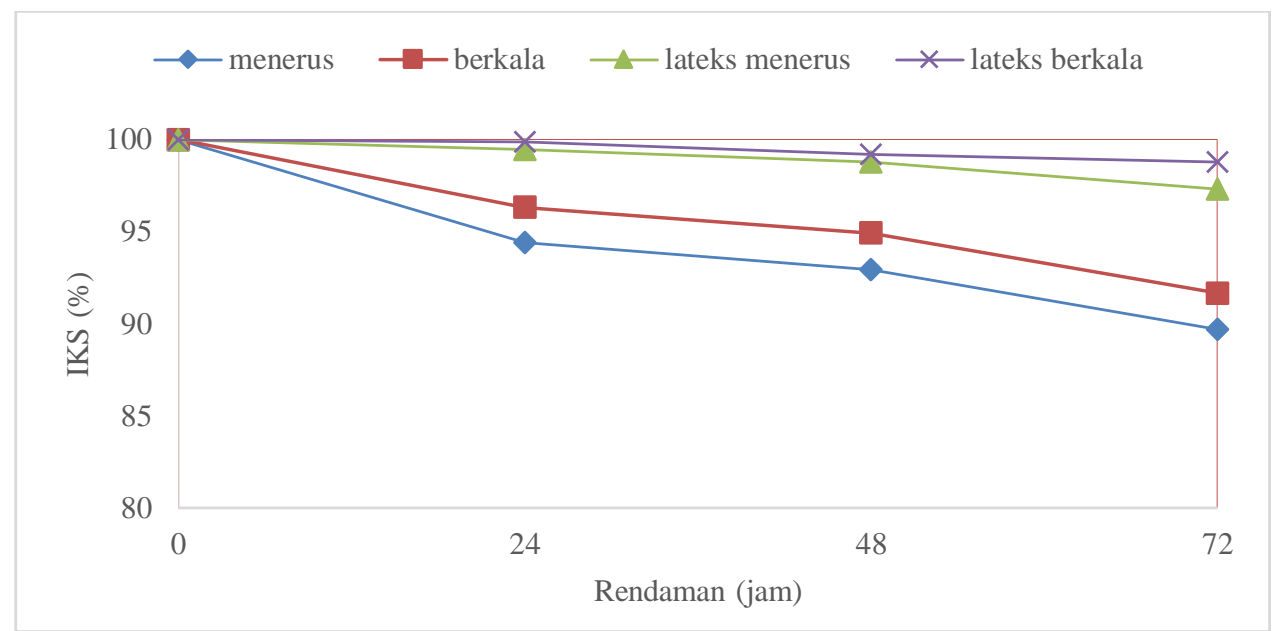

Gambar 8 Perbandingan Nilai IKS Akibat Rendaman Menerus dan Berkala

\section{KESIMPULAN}

Berdasarkan hasil analisis dan pembahasan dapat disimpulkan bahwa penambahan lateks meningkatkan kekuatan tarik campuran AC-WC berdasarkan hasil uji ITS. Adanya lateks pada campuran AC-WC dapat meningkatkan ketahanan terhadap rendaman menerus dan rendaman berkala, yaitu meningkatkan indeks kekuatan sisa dan mereduksi pengurangan IKS dengan bertambahnya lama rendaman. Rendaman menerus memberi dampak penurunan IKS yang lebih besar dibandingkan dengan rendaman berkala. Pada benda uji tanpa lateks, penurunan nilai IKS antara rendaman menerus dan rendaman berkala memiliki pola yang sama, namun pada benda uji dengan lateks pola penurunan nilai IKS berbeda.

\section{UCAPAN TERIMA KASIH}

Ucapan terima kasih disampaikan kepada Fakultas Teknik, Universitas Muhammadiyah Surakarta dan DRPM Kemenristekdikti, yang telah menyediakan fasilitas dan membantu pembiayaan penelitian melalui skema PTUPT, Surat Perjanjian Nomor Kontrak 199.62/A.3-III/LPPM/V/2019. Terima kasih juga diucapkan kepada Sugiarso yang telah memberi data propertis bahan penelitian. 


\section{DAFTAR PUSTAKA}

Abdulrahman, S., Hainin, M.R., Mohd-Satar, M.K.I., Hassan, N.A., dan Al Saffar, Z.H. 2020. Review on the Potentials of Natural Rubber in Bitumen Modification. IOP Conference Series: Earth and Environmental Science 476 (2020) 012067, IOP Publishing, doi:10. 1088/1755-1315/476/1/012067.

Al-Mansob, R.A., Ismail, A., Yusoff, N.I.M., Azhari, C.H., Karim, M.R., Alduri, A., dan Baghini, M.S. 2014. Rheological Characteristics of Epoxidised Natural Rubber Modified Bitumen. Applied Mechanics and Materials 505-506 174-179.

Amal, A.S. 2011. Pemanfaatan Getah Karet pada Aspal AC 60/70 terhadap Stabilitas Marshall pada Asphalt Treated Base (ATB). Media Teknik Sipil, 9 (1): 8-16.

Amiruddin, A.A., Sasmita, S.A.A., Ali, N., dan Renta, I. 2012. Kajian Eksperimental Campuran HRS-WC dengan Aspal Minyak dan Penambahan Aditif Lateks sebagai Bahan Pengikat. KoNTekS, 6: 133-140.

Badan Standardisasi Nasional. 2015. Cara Uji Ketahanan Campuran Beraspal Panas terhadap Kerusakan Akibat Rendaman. SNI 6753-2015. Jakarta.

Direktorat Jenderal Bina Marga. 2010. Spesifikasi Umum 2010 (Revisi 3). Jakarta.

Harnaeni, S.R, Pramesti, F.P., Budiarto, A., dan Setyawan, A. 2018. A Preliminary Study of Mechanistic Approach in Pavement Design to Accommodate Climate Change Effects. IOP Conference Series: Earth and Environmental Science, 129 (1).

Kamal, M.M., Hadithon, K.A., dan Abu Bakar, R. 2020. Natural Rubber Modified Asphalt. IOP Conf. Series: Earth and Environmental Science 498 (2020) 012001, IOP Publishing, doi:10.1088/1755-1315/498/1/012001.

Lee, D. 1969. Durability and Durability Tests for Paving Asphalt. Engineering Research Institute, IOWA State Highway Commission.

Nahyo, N., Sudarno, S., dan Setiadji, B.H. 2015. Durabilitas Campuran Hot Rolled SheetWearing Course (HRS-WC) Rendaman Menerus dan Berkala Air Rob. Jurnal Teknik Sipil, 13 (1): 124-135.

Prastanto, H., Firdaus, Y., Puspitasari, S., Ramadhan, A., dan Fallah, A. F. 2018. Sifat Fisika Aspal Modifikasi Karet Alam pada Berbagai Jenis dan Dosis Lateks Karet Alam. Pusat Penelitian Karet, Pusjatan, Bogor.

Putra, D. 2016. Pengaruh Rendaman Air Secara Menerus dan Berkala terhadap Durabilitas Campuran AC-WC (Asphalt Concrete-Wearing Course). Tesis tidak diterbitkan. Yogyakarta: Magister Sistem dan Teknik Transportasi, Universitas Gadjah Mada.

Putri, A.M. dan Suparma, L.B. 2009. Moisture Damage Evaluation of Asphalt Concrete Wearing Course (AC-WC) Utilizing Bantax and Clereng as Aggregate. Proceedings of the Eastern Asia Socienty for Transportation Studies, 7.

Rianung, S. 2007. Kajian Laboratorium Pengaruh Bahan Tambah Gondorukem pada Asphalt Concrete-Binder Course (AC-BC) terhadap Nilai Propertis Marshall dan Durabilitas. Tesis tidak diterbitkan. Semarang: Magister Teknik Sipil, Universitas Diponegoro. 
Sani, A., Mohd Hasan, M.R., Shariff, K.A., Jamshidi, A., Ibrahim, A.H., dan Poovaneshvaran, S. 2019. Engineering and Microscopic Characteristics of Natural Rubber Latex Modified Binders Incorporating Silane Additive. International Journal of Pavement Engineering, https://doi.org/10.1080/10298436.2019.1573319.

Siswanto, H. 2017. The Effect of Latex on Permanent Deformation of Asphalt Concrete Wearing Course. Procedia Engineering, 171: 1390-1394.

Siswanto, H. 2019. Effect of Latex to Minimize the Use of Asphalt in Asphalt Concrete Wearing Course. Materials Science Forum, 961: 39-44.

Sukirman, S. 2003. Perkerasan Lentur Jalan Raya. Bandung: Nova.

Sulistiyatno, A., Fajri, M.D.S.R., Mochtar, I.S., Kartika, A.A.G., dan Mulyana, M.A. 2012. Studi Pengaruh Genangan Air terhadap Kerusakan Jalan Aspal dan Perencanaan Subdrain untuk Ruas Jalan Rungkut Industri Raya, Jalan Rungkut Kidul Raya, Jalan Jemur Sari, Jalan Nginden Raya, Jalan Manyar, dan Jalan Mulyosari Raya. Jurnal Teknik POMITS, 1 (1): 1-6.

Sutanto, M.H., Bala, N., Al-Chodri, F., dan Sunarjono, S. 2018a. Effect of Hydrated Lime and Portland Cement on Asphalt Binders Using DSR. MATEC 203, 05006.

Sutanto, M.H., Bala, N., Zaro, K., dan Sunarjono, S. 2018b. Properties of Crumb Rubber and Latex Modified Asphalt Binders using Superpave Tests. MATEC 203, 05007.

Tajudin, A.N. dan Suparma, L.B. 2017. Pengaruh Rendaman pada Indirect Tensile Strength Campuran AC-BC dengan Limbah Plastik sebagai Agregat Pengganti. Media Komunikasi Teknik Sipil, 23 (2): 166-173.

Thanaya, I.N.A., Puranto, I.G.R., dan Nugraha, I.N.S. 2016. Studi Karakteristik Campuran Aspal Beton Lapis Aus (AC-WC) Menggunakan Aspal Penetrasi 60/70 dengan Penambahan Lateks. Media Komunikasi Teknik Sipil, 22 (2): 77-86.

Trisilvana, R.P., Krisna, S.P., Djakfar, L., dan Bowoputro, H. 2014. Pengaruh Penambahan Alami Lateks (Getah Karet) terhadap Kinerja Marshall Aspal Porus. Skripsi tidak diterbitkan. Malang: Jurusan Teknik Sipil, Universitas Brawijaya.

Usman, A., Izzaty, N., Ibrahim, R., Sutanto, M. H., dan Sunarjono, S., 2019. Storage Stability and Morphology of Latex Modified Bitumen. International Journal of Innovative and Exploring Engineering (IJITEE), ISSN: 2278-3075, 9 (1): 4435-4440.

Wen, Y., Wang, Y., Zhao, K., dan Sumalee, A. 2015. The Use of Natural Rubber Latex as A Renewable and Sustainable Modifier of Asphalt Binder. International Journal of Pavement Engineering, 18 (6): 547-559.

Wijaya, E., Derren, J.J., Antonius, D., dan Rachmansyah. 2016. Studi Eksperimental Pengaruh Penambahan Zat Aditif Lateks pada Beton Aspal terhadap Stabilitas. Jurnal Teknik dan Ilmu Komputer, 5 (20): 375-383. 